\title{
Editöre Mektup:
}

\section{KKTC'de Yaşayan 5-6 Yaş Çocukların Tablet ve Cep Telefonu Kullanımına İlişkin Ebeveyn Görüşlerinin İncelenmesi}

\author{
Neslihan DURMUŞOĞLU SALTALI \\ Girne Amerikan Üniversitesi \\ ndsaltali@gmail.com \\ Mehmet Ali ATEŞ \\ Girne Amerikan Üniversitesi \\ $\underline{\text { mehmetaliates@gau.edu.tr }}$
}

Gönderilme Tarihi: 20/10/2019

Yayınlanma Tarihi: 29/11/2019

DOI: $\underline{10.30855 / \text { gjes.2019.05.03.008 }}$

\section{Sayın Editör,}

M. A. Ateş ile birlikte yürüttüğümüz “KKTC'de Yaşayan 5-6 Yaş Çocukların Tablet ve Cep Telefonu Kullanımına İlişkin Ebeveyn Görüşlerinin İncelenmesi” başlıklı araştırma makalemiz, derginizin 2019 yılında basılan 5. Cilt 1. sayısında yayınlanmıştır. Yayının tartışma bölümünde araştırma bulguları tartışılırken araştırmaya katılan ebeveynlerin hiçbirinin cep telefonu ve tablet kullanımının çocuklar üzerindeki olumsuz etkileri arasında obezite riskine değinmediği söylenilmiştir. Ardından halbuki literatürde birçok kaynakta dijital teknoloji kullanımının çocuklar üzerindeki riskleri arasında obezitenin de yer aldığı söylenmiş ve bu yayınlar arasından yurt içinden ve yurt dişından birkaç örnek verilmiştir (Calvert, Staiano ve Bond, 2013; Mustafaoğlu ve Yasacı, 2018; Robinson, 1999). Burada literatürde oldukça eski tarihten beri dijital teknolojilerin uzun süreli kullanımının yarattı̆̆ı obezite riskine değinildiğini göstermesi bakımından 1999 ve 2013 yılından iki yabancı kaynak, daha sonra da hem Türkiye'de bu riske değinen nitelikli bir çalışma olması hem de güncel olması dolayısıyla Yasacı ve Mustafaoğlu

Durmuşoğlu Saltalı, N., \& Ateş, M. A. (2019). Editöre mektup: KKTC'de yaşayan 5-6 yaş çocukların tablet ve cep telefonu kullanımına ilişkin ebeveyn görüşlerinin incelenmesi. Gazi Eğitim Bilimleri Dergisi, 5(3), 179-180. DOI: https://dx.doi.org/10.30855/gjes.2019.05.03.008

Dergi Web Sayfasi: http://dergipark.gov.tr/gebd 
(2018) tarafından Bağımlılık Dergisi'nde yayınlanan “Dijital oyun oynamanın çocukların ruhsal ve fiziksel sağlığı üzerine olumsuz etkileri" isimli yayına atıfta bulunulmuştur.

Ancak, Yasacı ve Mustafaoğlu (2019) tarafından derginizin 2019 yılı 5. Cilt 2. sayısında sunulan editöre mektupla, araştırmamızda sehven kendilerinin yayınında dijital teknoloji kullanımının çocuklar üzerindeki riskleri arasında obeziteye yer verilmediğini söylediğimiz bildirilmiştir. Halbuki ilgili cümle dikkatle değerlendirilirse bu üç yayının dijital teknoloji kullanımının yarattığı obezite riskine örnek olarak verildiği, tarafımızca yürütülen araştırmaya katılan ebeveynlerin bu riske hiç değinmediklerinin söylendiği anlaşılacaktır. Cümlenin uzun oluşuna bağlı sehven böyle bir anlam kargaşası yaşanmış olabileceği kanaatindeyiz.

Sonuç olarak, yazarlara çocukların dijital teknoloji kullanımının çocuklar üzerinde yarattığı etkilere değinen ülkemizde yürüttükleri çalışmalarla literatüre sağladıkları katkılar dolayısıyla teşekkür ederiz. Saygılarımızla.

\section{KAYNAKLAR}

Calvert, S. L., Staiano, A. E., \& Bond, B. J. (2013). Electronic gaming and the obesity crisis. New Directions for Child and Adolescent Development, 139, 51-57. http://doi.org/10.1002/cad.20031.

Mustafaoğlu, R., \& Yasacı, Z. (2018). Dijital oyun oynamanın çocukların ruhsal ve fiziksel sağlığı üzerine olumsuz etkileri. Bağımlılık Dergisi, 19(3), 51-58.

Robinson, T. (1999). Reducing children's television viewing to prevent obesity. JAMA, 282(16), 1561-1567. 